\title{
Accumulation and partitioning of heavy metals in mangroves: A synthesis of field-based studies
}

\author{
Geoff R. MacFarlane ${ }^{\mathrm{a}, *}$, Claudia E. Koller ${ }^{\mathrm{a}}$, Simon P. Blomberg ${ }^{\mathrm{b}}$ \\ ${ }^{a}$ School of Environmental and Life Sciences, University of Newcastle, Callaghan, NSW, Australia \\ ${ }^{\mathrm{b}}$ Centre for Resource and Environmental Studies, Australian National University, ACT, Australia
}

Received 16 February 2007; received in revised form 18 April 2007; accepted 20 April 2007

Available online 8 June 2007

\begin{abstract}
We report the findings of a comparative analysis examining patterns of accumulation and partitioning of the heavy metals copper $(\mathrm{Cu})$, lead $(\mathrm{Pb})$ and zinc $(\mathrm{Zn})$ in mangroves from available field-based studies to date, employing both species level analyses and a phylogenetic approach. Despite mangroves being a taxonomically diverse group, metal accumulation and partitioning for all metals examined were broadly similar across genera and families. Patterns of metal accumulation were also similar regardless of whether species were classified as salt secreting or non-secreting. Metals were accumulated in roots to concentrations similar to those of adjacent sediments with root bio-concentration factors (BCF; ratio of root metal to sediment metal concentration) of $\leqslant 1$. Root BCFs were constant across the exposure range for all metals. Metal concentrations in leaves were half that of roots or lower. Essential metals $(\mathrm{Cu}$ and $\mathrm{Zn}$; translocation factors (TF; ratio of leaf metal to root metal concentration) of 0.52 and 0.53 , and leaf BCFs of 0.47 and 0.51 , respectively) showed greater mobility than non-essential metals $(\mathrm{Pb}$; TF of 0.31 and leaf $\mathrm{BCF}$ of 0.11$)$. Leaf $\mathrm{BCF}$ for the essential metals $\mathrm{Cu}$ and $\mathrm{Zn}$ decreased as environmental concentrations increased. The non-essential metal $\mathrm{Pb}$ was excluded from leaf tissue regardless of environmental concentrations. Thus mangroves as a group tend to operate as excluder species for non-essential metals and regulators of essential metals. For phytoremediation initiatives, mangrove ecosystems are perhaps best employed as phytostabilisers, potentially aiding in the retention of toxic metals and thereby reducing transport to adjacent estuarine and marine systems.
\end{abstract}

(c) 2007 Elsevier Ltd. All rights reserved.

Keywords: Bioaccumulation; Mangrove; Heavy metals; Copper; Lead; Zinc

\section{Introduction}

Mangrove ecosystems are diverse intertidal wetlands, commonly situated in tropical, sub-tropical and temperate coastal systems. They are highly productive and play a vital role as a major primary producer within estuarine systems. Mangrove systems serve as habitat and nursery area for many juvenile fish and crustaceans, which have both direct and indirect socio-economic importance. They also provide erosion mitigation and stabilisation for adjacent coastal landforms (Harty, 1997).

\footnotetext{
${ }^{*}$ Corresponding author. Tel.: +61 24917858; fax +61 249216923.

E-mail address: Geoff.MacFarlane@newcastle.edu.au (G.R. MacFarlane).
}

Despite their importance, mangrove ecosystems have been exploited and subject to inappropriate management practices in terms of land reclamation and unsustainable forestry, as well as agricultural and aquaculture initiatives (West et al., 1983; Eong, 1995). As a consequence of their close proximity to urban development, they have experienced significant direct contaminant input. Among the major pollutants from anthropogenic inputs are heavy metals (MacFarlane, 2002).

Metallic enrichment of mangrove environments arises from urban and agricultural runoff, industrial effluents, boating and recreational use of waterbodies, chemical spills, sewage treatment plants, leaching from domestic garbage dumps and mining operations (Peters et al., 1997). The metal pollutants most commonly entering estuarine 
systems through industrial sources (based on frequency of detection) are $\mathrm{Cu}, \mathrm{Pb}$ and $\mathrm{Zn}$ (Mills, 1995). These metals consequently occur in high concentrations in many estuaries, with concentrations reaching up to $1000 \mu \mathrm{g} \mathrm{Cu} \mathrm{g}^{-1}$, $1000 \mu \mathrm{g} \mathrm{Pb} \mathrm{g}^{-1}$ and $2000 \mu \mathrm{g} \mathrm{Zn}^{-1}$ in contaminated sediments (Irvine and Birch, 1998).

Despite their potential exposure to metal contaminated sediments, mangroves appear to be highly tolerant to heavy metals. Numerous laboratory-based toxicity trials suggest that the concentrations of metals required to impart significant negative effects on mangroves may be several orders of magnitude higher when compared to their aquatic and terrestrial floral counterparts. Thomas and Eong (1984) have found no adverse effects on the growth of seedlings of Rhizophora mucronata Lam. and Avicennia alba B1. treated with $\mathrm{Zn}\left(10-500 \mu \mathrm{g} \mathrm{ml}^{-1}\right)$ and $\mathrm{Pb}\left(50-250 \mu \mathrm{g} \mathrm{ml}^{-1}\right)$. In Kandelia candel (L.) Druce seedlings, inhibition of leaf and root development was observed only at the highest applied metal concentrations (400 $\mathrm{mg} \mathrm{kg}^{-1} \mathrm{Cu}$ and $\mathrm{Zn}$ ) (Chiu et al., 1995). Similarly, MacFarlane and Burchett (2002) found $\mathrm{Pb}(0$ $800 \mu \mathrm{g} \mathrm{g}^{-1}$ ) had little negative effect on Avicennia marina (Forsk.) Vierh. seedlings. Copper and $\mathrm{Zn}$ showed low relative toxicities in terms of emergence and biomass/growth in A. marina with $\mathrm{LC}_{50}$ values for emergence $566 \mu \mathrm{g} \mathrm{g}^{-1}$ for $\mathrm{Cu}$ and $580 \mu \mathrm{g} \mathrm{g}^{-1}$ for $\mathrm{Zn}$. The LOEC values for reductions in growth/biomass parameters were $400 \mu \mathrm{g} \mathrm{g}^{-1}$ for $\mathrm{Cu}$ and $500 \mu \mathrm{g} \mathrm{g}^{-1}$ for $\mathrm{Zn}$.

Tolerance has been in part attributed to the ability of mangroves to exclude metals or regulate uptake of metals at the root level and limit translocation to the shoot (MacFarlane and Burchett, 2002). A number of studies have found metals such as $\mathrm{Cu}, \mathrm{Zn}, \mathrm{Pb}, \mathrm{Fe}, \mathrm{Mn}$ and $\mathrm{Cd}$ to be accumulated predominantly in root tissue, rather than in foliage, in numerous mangrove species in the field, such as Avicennia spp., Rhizophora spp. and Kandelia spp. (Peters et al., 1997). Data seem to suggest that for some mangrove taxa at least, concentrations of translocated metals are low, with bio-concentration factors (BCF; ratio of leaf metal to corresponding sediment metal concentration) ranging from $<0.01$ in Rhizophora mangle to 0.06 for other species such as A. marina (Lacerda, 1997). Other studies suggest that mangroves may accumulate and translocate some metals with leaf BCFs greater than one, e.g. 1.5-2.4 for A. marina (Sadiq and Zaidi, 1994), 1.7 for Aegiceras corniculatum and 1.2 for Kandelia candel (Chen et al., 2003), thereby meeting established criteria for hyperaccumulating species (Baker and Whiting, 2002). To date, little attention has been directed at the systematic examination of cross-species patterns of metal accumulation and translocation in mangroves.

The word 'mangrove' is often employed interchangeably to refer to either the plants (trees/shrubs) which reside in intertidal communities, and/or to the community itself (Tomlinson, 1986). Within the current context, we reserve the use of the term to apply strictly to the constituent plants rather than the community. Mangroves are a heterogeneous group of 80 taxonomically diverse species, in 30 genera and
20 families (Field, 1995). The classification of a plant as a mangrove largely rests on its exclusive distribution within intertidal estuarine environments rather than on any distinct botanical, taxonomic or phylogenetic convention (Tomlinson, 1986). Various taxa have evolved distinct morphological specialisations for dealing with anoxic sediments, periodic inundation and maintaining osmotic balance in (hyper)saline environments. Members of the families Rhizophoraceae possess aerial stilts while members of the families Avicennaceae and Sonneratiaceae possess aerial extensions of the subterranean root system termed 'pneumatophores'. These differing morphologies function to enable gaseous exchange and oxygenation for respiration in an anoxic environment (Hutchings and Saenger, 1987). More landward families inhabiting less anoxic sediments, such as members of Myrsinaceae, possess no aerial roots. The anatomy of the nutritive root varies widely among taxa, even within families (Lawton et al., 1981). Roots of most mangrove species possess two main barriers to the transport of $\mathrm{Na}^{+}$and other ions to the vasculature, including layers of the root epidermis and the endodermis. Mechanisms and relative contributions of these tissues to the regulation/ exclusion of ion transport vary dependent on whether a species is a salt secretor or a non-secretor (predominantly excluders), with secretors generally showing greater ion mobility and translocation (Kramer and Preston, 1978; Lawton et al., 1981). Heavy metal uptake in mangroves is also regulated at the root endodermis through modifying uptake from predominantly apoplastic to selective symplastic transport. The contribution of each tissue type is dependent on the molecular properties of the plamsalemma (i.e. specific membrane transport proteins) and on the metal in question (MacFarlane and Burchett, 2000; Greger, 2004).

Some genera such as Aegiceras and Avicennia secrete excessive $\mathrm{Na}^{+}$and $\mathrm{K}^{+}$through specialised glands or glandular trichomes on abaxial and adaxial leaf surfaces. Such mechanisms are absent in non-secretors, e.g. Rhizophora and Sonneratia (MacFarlane and Burchett, 1999). Indeed mangroves, and a number of other estuarine halophytes with glandular tissue, have been observed to excrete heavy metals concomitantly with other solutes (Neumann et al., 1995; MacFarlane and Burchett, 2000). It stands to reason that variation in morphology/function of nutritive root tissue and glandular tissue to deal with the challenges of excess cations in saline environments may confer significant implications for metal accumulation, transport, partitioning and excretion among species.

These issues lead us to ask whether consistent patterns of metal accumulation occur across phylogenetically distinct taxa inhabiting contaminated estuarine sediments, or conversely, if mangrove taxa exhibit variation in accumulation strategies. Do species vary in terms of metal accumulation dependent on whether their predominant strategy of dealing with salinity is salt secretion or non-secretion (predominantly exclusion at the root)? Equally, do patterns of metal accumulation vary across taxa with sediment metal loadings? 
We chose to investigate these questions using a dataset of published studies from the literature, where metal concentrations have been quantified in mangrove sediments and mangrove root and leaf tissue under field conditions.

\section{Methods}

\subsection{Data collection}

A survey of the literature was conducted to arrive at a total of 21 published studies where accumulation of the metals $\mathrm{Cu}, \mathrm{Pb}$ and $\mathrm{Zn}$ have been assessed in mangrove species under field conditions worldwide. Copper, $\mathrm{Pb}$ and $\mathrm{Zn}$ were chosen as representative trace metals from classes of metals which are essential $(\mathrm{Cu}$ and $\mathrm{Zn})$ or non-essential $(\mathrm{Pb})$ to plant metabolism, as the patterns of accumulation are likely to vary dependant on essentiality (Baker, 1981). Copper, $\mathrm{Pb}$ and $\mathrm{Zn}$ are also metals which occur at high concentrations in many contaminated locales and are considered significant metal contaminants due to high frequency of detection/occurrence (Mills, 1995). Only 'true mangroves' were considered appropriate for inclusion as candidate species. True mangroves exhibit fidelity to the mangal environment, possess morphological adaptations for intertidal environments, display physiological mechanisms for salt exclusion and/or regulation and exhibit taxonomic separation from terrestrial elements. True mangroves may be further delimited into major mangrove elements and minor mangrove elements depending on their ability to form a conspicuous element or monospecific stands within a mangal (Tomlinson, 1986).

Only those studies were included where metals were quantified on a dry weight/weight basis (ppm or $\mu \mathrm{g} \mathrm{g}^{-1}$ ), or could be calculated from original data. Where sampling was conducted at various locations with differing sediment metal levels, ranges were presented. If temporal monitoring of metals in sediment and plant tissue was conducted, values were averaged over the sampling period. Where metals were analysed at varying depths of the sediment profile, an average of horizons was calculated.

Three relative measures of metal uptake were chosen to enable interspecific comparisons of metal uptake/distribution and comparisons among metals. Root BCF (ratio of root metal to sediment metal concentration) and leaf $\mathrm{BCF}$ were calculated to assess concentrations in specific tissue types relative to environmental loadings. Translocation factors (TF; ratio of leaf metal to root metal concentration) were calculated to enable assessment of transport of accumulated metal from root to shoot. Root BCFs, leaf BCFs and TFs represent averages of original data.

When amassing data from a variety of unrelated studies, significant problems arise in terms of the validity of the data obtained for comparative purposes. Depending on the location of sampling and the sediment type encountered, uptake of metals may vary significantly as anoxic sediments high in sulphur and organic content may exhibit low metal bioavailability (Harbison, 1986). Thus a specific
BCF will reflect the species ability to accumulate a particular metal in a particular habitat, but this may be an underestimate of the species' ability to accumulate the metal in question under sediment conditions where metals exhibit greater availability. Metal availability may vary depending on numerous other site specific sediment physicochemical considerations including the cation exchange capacity, $\mathrm{pH}$, redox status, metal speciation, nutrient availability and salinity of sediments (Greger, 2004). For many species, data are available across a limited range of sediment contaminant loadings, hence the patterns observed may be skewed and not be representative of a particular species' response in highly contaminated locales. Sample size differs both within and across studies for some species, thus anomalous data may unduly weigh on interpretation.

Analysis methodology for metals varies among candidate studies, in that different acids and concentrations are employed. However, none of sediment metal concentrations came from digestions which included HF, the only method that extracts metals from the silicate matrix. Of the studies that reported results obtained from certified sediment reference materials (SRM), extraction with $\mathrm{H}_{2} \mathrm{O}_{2}+\mathrm{HCl}+\mathrm{HNO}_{3}+\mathrm{HClO}_{4}$ gave results within $10 \%$ of the reference material (Silva et al., 1990). Microwave digestion in $\mathrm{HNO}_{3}+\mathrm{HCl}$ within $15 \%$ of SRM (Marchand et al., 2006) and hotplate digestion in $\mathrm{HNO}_{3}+\mathrm{H}_{2} \mathrm{O}_{2}$ within 17\% of SRM (MacFarlane, 2002; MacFarlane et al., 2003). Other acids used were $\mathrm{HNO}_{3}+\mathrm{HClO}_{3}$ (Peng et al., 1997; Alongi et al., 2003), $\mathrm{HNO}_{3}+\mathrm{HSO}_{3}$ (Ong Che, 1999), and $0.1 \mathrm{~N} \mathrm{HCl}$ (Chiu and Chou, 1991) or $0.1 \mathrm{M} \mathrm{HCl}$ (Lacerda, 1997) to examine the weakly bound fraction. A comparison of digests obtained for four sediment reference materials by aqua regia extraction and $\mathrm{HNO}_{3}+\mathrm{H}_{2} \mathrm{O}_{2}$ extraction in a microwave and heating block showed consistent recovery of $87 \pm 1.5 \%$ for $\mathrm{Cu}, 78 \pm 0.9 \%$ for $\mathrm{Zn}$ (except for PACS-1 at $49 \pm 9.2 \%$ ) and lower and more variable recovery for $\mathrm{Pb}(62 \pm 4.8 \%)$. Overall, there was no difference between the three extraction methods tested (Tam and Yao, 1999). Thus estimates of sediment metal loadings among studies may differ somewhat based on the extraction method employed, though this is likely to affect BCFs to a greater degree than TFs, as plant tissues dissolve much more readily than sediments in weak acid digestions.

Finally, significant variation may exist in data depending on the nature of sampling protocols for the collection of vegetation, including age/life stage of individual sampled, leaf age, leaf/branch position, position in the stand and level of replication. Environmental variation among studies in terms of temperature, light and frequency of inundation may also influence metal uptake patterns (Greger, 2004). Thus we acknowledge that numerous biases may exist in the final dataset. Nonetheless, for species where heavy metal accumulation has been assessed under field conditions, it is instructive to attempt to ascertain broad accumulation patterns, though the data should be viewed cautiously. 
Table 1

Distribution of the heavy metals: (a) copper, (b) zinc and (c) lead $\left(\mu \mathrm{g} \mathrm{g}^{-1}\right)$ in sediment and in the roots and leaves of 19 mangrove species based on the published literature

\begin{tabular}{|c|c|c|c|c|c|c|c|c|}
\hline Family & Species & Location & Sediment & Roots & Leaves & Root BCF & Leaf BCF & $\mathrm{TF}$ \\
\hline \multicolumn{9}{|l|}{ a. Copper $(\mathrm{Cu})$} \\
\hline \multirow[t]{2}{*}{ Acanthaceae } & Acanthus ilicifolius & Hainan Island, China ${ }^{6}$ & & & 2.1 & & 0.07 & \\
\hline & & Mai Po, Hong Kong ${ }^{11}$ & 50 & 41 & & 0.82 & & \\
\hline \multirow[t]{14}{*}{ Avicenniaceae } & Avicennia marina & Saudi coast ${ }^{13}$ & 1.8 & & 4.4 & & 2.42 & \\
\hline & & Ting Kok, Hong Kong ${ }^{2}$ & 13 & 13 & 16 & 1.02 & 1.26 & 1.23 \\
\hline & & W. Australia ${ }^{1}$ & 16 & 18 & 7.3 & 1.16 & 0.47 & 0.40 \\
\hline & & Shenzhen, S. China ${ }^{20}$ & 36 & 14 & 5 & 0.39 & 0.14 & 0.36 \\
\hline & & Shenzhen, China ${ }^{12}$ & 36 & 13 & 5.2 & 0.37 & 0.15 & 0.39 \\
\hline & & Karachi, Pakistan ${ }^{19}$ & $12-56$ & & $3.2-14$ & & 0.27 & \\
\hline & & SE Australia ${ }^{8}$ & 61 & 101 & 9 & 1.66 & 0.15 & 0.09 \\
\hline & & SE Australia ${ }^{7}$ & $1-102$ & & $3.0-20$ & & 0.25 & \\
\hline & & N. Australia ${ }^{14}$ & $25-134$ & & $9.8-26$ & & 0.28 & \\
\hline & & Hainan Island, China ${ }^{6}$ & & & 6.3 & & 0.46 & \\
\hline & & & & & & 0.92 & 0.58 & 0.50 \\
\hline & Avicennia officialis & E. India ${ }^{15}$ & 6.3 & & 2.9 & & 0.47 & \\
\hline & & India $^{18}$ & 303 & & 102 & & 0.33 & \\
\hline & & & & & & & 0.40 & \\
\hline \multirow[t]{3}{*}{ Combretaceae } & Laguncularia racemosa & Pacific Panama $^{4}$ & 56 & & 3.7 & & 0.07 & \\
\hline & & SE Brazil $^{9}$ & $18-80$ & & $7.0-10$ & & 0.25 & \\
\hline & & & & & & & 0.16 & \\
\hline Meliaceae & Xylocarpus granatum & E. India ${ }^{15}$ & 3.8 & & 2.1 & & 0.57 & \\
\hline \multirow[t]{6}{*}{ Myrsinaceae } & Aegiceras cornuculatum & Ting Kok, Hong Kong ${ }^{2}$ & 10 & 16 & 17 & 1.62 & 1.66 & 1.03 \\
\hline & & N. Australia ${ }^{14}$ & 34 & & 9.6 & & 0.28 & \\
\hline & & Shenzhen, China ${ }^{17}$ & 41 & & 4.1 & & 0.10 & \\
\hline & & Mai Po, Hong Kong ${ }^{11}$ & 46 & 33 & & 0.71 & & \\
\hline & & Hainan Island, China ${ }^{6}$ & & & 7.7 & & 0.56 & \\
\hline & & & & & & 1.16 & 0.65 & \\
\hline \multirow[t]{21}{*}{ Rhizophoraceae } & Bruguiera cylindrica & E. India ${ }^{15}$ & 2.8 & & 1.9 & & 0.69 & \\
\hline & Bruguiera gymnorrhiza & Hainan Island, China ${ }^{6}$ & & & 7.8 & & 0.57 & \\
\hline & Bruguiera sexangula & Hainan Island, China ${ }^{6}$ & & & 7.8 & & 0.56 & \\
\hline & Ceriops decandra & E. India ${ }^{15}$ & 2.8 & & 1.2 & & 0.41 & \\
\hline & Ceriops tagal & Hainan Island, China ${ }^{6}$ & & & 5.4 & & 0.39 & \\
\hline & & N. Australia ${ }^{14}$ & $31-80$ & & $7.4-17$ & & 0.28 & \\
\hline & & & & & & & 0.34 & \\
\hline & Kandelia candel & Ting Kok, Hong Kong ${ }^{2}$ & 8.8 & 12 & 11 & 1.33 & 1.20 & 0.90 \\
\hline & & Shenzhen, China ${ }^{17}$ & 41 & & 4.1 & & 0.10 & \\
\hline & & Mai Po, Hong Kong ${ }^{11}$ & 42 & 24 & & 0.58 & & \\
\hline & & Tamshui estuary, Taiwan ${ }^{13}$ & $4.5-55$ & $35-165$ & $3.1-10$ & 3.36 & 0.21 & 0.14 \\
\hline & & Hainan Island, China ${ }^{6}$ & & & 3.1 & & 0.23 & \\
\hline & & Fujian, China ${ }^{20}$ & & & & & 0.07 & \\
\hline & & & & & & 1.76 & 0.36 & 0.52 \\
\hline & Rhizophora mangle & Rio de Janeiro, Brazil ${ }^{16}$ & 2.7 & 5.1 & 0.1 & 1.90 & 0.04 & 0.02 \\
\hline & Rhizophora mucronata & E. India ${ }^{15}$ & 2.8 & & 1.8 & & 0.63 & \\
\hline & Rhizophora stylosa & W. Australia ${ }^{1}$ & 14 & 6.5 & 3.7 & 0.47 & 0.27 & 0.57 \\
\hline & & Yingluo Bay, China ${ }^{21}$ & 19 & 1.1 & 0.6 & 0.06 & 0.03 & 0.55 \\
\hline & & N. Australia ${ }^{14}$ & 39 & & 16 & & 0.42 & \\
\hline & & Hainan Island, China ${ }^{6}$ & & & 2.4 & & 0.18 & \\
\hline & & & & & & 0.27 & 0.22 & 0.56 \\
\hline \multirow[t]{4}{*}{ Sonneratiaceae } & Sonneratia apetala & Guangdong, China $^{5}$ & & & & & 1.44 & \\
\hline & Sonneratia caseolaris & Hainan Island, China ${ }^{6}$ & & & 6.8 & & 0.49 & \\
\hline & Sonneratia ovata & Hainan Island, China ${ }^{6}$ & & & 7.4 & & 0.54 & \\
\hline & & & & & Average & 1.1 & 0.47 & 0.52 \\
\hline \multicolumn{9}{|l|}{ b. Lead $(\mathrm{Pb})$} \\
\hline \multirow[t]{2}{*}{ Acanthaceae } & Acanthus ilicifolius & Hainan Island, China ${ }^{6}$ & & & 0.03 & & 0.00 & \\
\hline & & Mai Po, Hong Kong ${ }^{11}$ & 220 & 33 & & 0.15 & & \\
\hline \multirow[t]{6}{*}{ Avicenniaceae } & Avicennia marina & Saudi coast ${ }^{13}$ & 12 & & 6.9 & & 0.58 & \\
\hline & & N. Australia ${ }^{14}$ & $8.0-27$ & & $1.1-4.7$ & & 0.15 & \\
\hline & & Shenzhen, S. China ${ }^{20}$ & 31 & 3.4 & 1.8 & 0.11 & 0.06 & 0.53 \\
\hline & & Ting Kok, Hong Kong ${ }^{2}$ & 33 & 15 & 8.0 & 0.44 & 0.24 & 0.55 \\
\hline & & Shenzhen, China ${ }^{17}$ & 34 & 3.5 & 1.9 & 0.10 & 0.06 & 0.54 \\
\hline & & Karachi, Pakistan ${ }^{19}$ & $32-59$ & & $11-23$ & & 0.36 & \\
\hline
\end{tabular}


Table 1 (continued)

\begin{tabular}{|c|c|c|c|c|c|c|c|c|}
\hline Family & Species & Location & Sediment & Roots & Leaves & Root BCF & Leaf BCF & $\mathrm{TF}$ \\
\hline & & SE Australia ${ }^{8}$ & 100 & 164 & 5 & 1.64 & 0.05 & 0.03 \\
\hline & & SE Australia ${ }^{7}$ & $3-414$ & & $0.1-2.9$ & & 0.04 & \\
\hline & & Hainan Island, China ${ }^{6}$ & & & 0.02 & & 0.00 & \\
\hline & & & & & & 0.57 & 0.17 & 0.41 \\
\hline & Avicennia officialis & India $^{18}$ & 1484 & & 168 & & 0.11 & \\
\hline \multirow[t]{3}{*}{ Combretaceae } & Laguncularia racemosa & Pacific Panama ${ }^{4}$ & 78 & & 6.1 & & 0.08 & \\
\hline & & SE Brazil ${ }^{9}$ & $20-130$ & & $1.0-8.9$ & & 0.07 & \\
\hline & & & & & & & 0.08 & \\
\hline \multirow[t]{4}{*}{ Myrsinaceae } & Aegiceras cornuculatum & N. Australia ${ }^{14}$ & 12 & & 1.6 & & 0.13 & \\
\hline & & Ting Kok, Hong Kong ${ }^{2}$ & 29 & 27 & 7.9 & 0.94 & 0.28 & 0.29 \\
\hline & & Mai Po, Hong Kong ${ }^{11}$ & 215 & 30 & & 0.14 & & \\
\hline & & & & & & 0.54 & 0.20 & \\
\hline \multirow[t]{18}{*}{ Rhizophoraceae } & Bruguiera gymnorrhiza & Hainan Island, China ${ }^{6}$ & & & 0.02 & & 0.01 & \\
\hline & Bruguiera sexangula & Hainan Island, China ${ }^{6}$ & & & 0.03 & & 0.01 & \\
\hline & Ceriops tagal & Hainan Island, China ${ }^{6}$ & & & 0.03 & & 0.01 & \\
\hline & & N. Australia ${ }^{14}$ & $9.7-20$ & & $1.6-6.1$ & & 0.27 & \\
\hline & & & & & & & 0.14 & \\
\hline & Kandelia candel & Guangzhou, China ${ }^{10}$ & 23 & 67 & 2.4 & 2.87 & 0.10 & 0.04 \\
\hline & & Ting Kok, Hong Kong ${ }^{2}$ & 29 & 28 & 11 & 0.95 & 0.37 & 0.39 \\
\hline & & Guangzhou, China ${ }^{10}$ & 32 & 63 & 4.8 & 1.99 & 0.15 & 0.08 \\
\hline & & Tamshui estuary, Taiwan ${ }^{13}$ & $11-36$ & $16-77$ & $1.0-5.0$ & 2.03 & 0.17 & 0.11 \\
\hline & & Mai Po, Hong Kong ${ }^{11}$ & 162 & 40 & & 0.25 & & \\
\hline & & Hainan Island, China ${ }^{6}$ & & & 0.04 & & 0.01 & \\
\hline & & Fujian, China ${ }^{20}$ & & & & & 0.04 & \\
\hline & & & & & & 1.62 & 0.14 & 0.15 \\
\hline & Rhizophora mangle & Rio de Janeiro, Brazil ${ }^{16}$ & 9.9 & 0.2 & 0.01 & 0.02 & 0.00 & 0.07 \\
\hline & Rhizophora stylosa & Yingluo Bay, China ${ }^{21}$ & 10 & 0.9 & 0.8 & 0.09 & 0.08 & 0.83 \\
\hline & & N. Australia ${ }^{14}$ & 16 & & 2.2 & & 0.14 & \\
\hline & & Hainan Island, China ${ }^{6}$ & & & 0.04 & & 0.00 & \\
\hline & & & & & & & 0.07 & \\
\hline \multirow[t]{3}{*}{ Sonneratiaceae } & Sonneratia caseolaris & Hainan Island, China ${ }^{6}$ & & & 0.03 & & & \\
\hline & Sonneratia ovata & Hainan Island, China ${ }^{6}$ & & & 0.02 & & & \\
\hline & & & & & Average & 0.84 & 0.11 & 0.31 \\
\hline \multicolumn{9}{|l|}{ c. Zinc $(\mathrm{Zn})$} \\
\hline \multirow[t]{2}{*}{ Acanthaceae } & Acanthus ilicifolius & Hainan Island, China ${ }^{6}$ & & & 60 & & 0.57 & \\
\hline & & Mai Po, Hong Kong ${ }^{11}$ & 321 & 207 & & 0.64 & & \\
\hline \multirow[t]{14}{*}{ Avicenniaceae } & Avicennia marina & Saudi coast ${ }^{13}$ & 7.3 & & 11 & & 1.56 & \\
\hline & & W. Australia ${ }^{1}$ & 34 & 16 & 14 & 0.48 & 0.42 & 0.88 \\
\hline & & Ting Kok, Hong Kong ${ }^{2}$ & 55 & 16 & 15 & 0.29 & 0.28 & 0.96 \\
\hline & & Shenzhen, S. China ${ }^{20}$ & 99 & 70 & 23 & 0.71 & 0.23 & 0.33 \\
\hline & & Shenzhen, China ${ }^{12}$ & 106 & 79 & 23 & 0.75 & 0.22 & 0.29 \\
\hline & & N. Australia ${ }^{14}$ & $46-210$ & & $16-52$ & & 0.31 & \\
\hline & & SE Australia ${ }^{8}$ & 243 & 295 & 25 & 1.21 & 0.10 & 0.08 \\
\hline & & SE Australia ${ }^{7}$ & $10-289$ & & $12-46$ & & 0.35 & \\
\hline & & Karachi, Pakistan $^{19}$ & $35-67$ & & $10-19$ & & 0.29 & \\
\hline & & Hainan Island, China ${ }^{6}$ & & & 20 & & 0.70 & \\
\hline & & & & & & 0.69 & 0.45 & 0.51 \\
\hline & Avicennia officialis & E. India ${ }^{15}$ & 1.5 & & 1.2 & & 0.8 & \\
\hline & & India $^{18}$ & 764 & & 120 & & 0.16 & \\
\hline & & & & & & & 0.48 & \\
\hline \multirow[t]{3}{*}{ Combretaceae } & Laguncularia racemosa & Pacific Panama ${ }^{4}$ & 105 & & 36 & & 0.34 & \\
\hline & & SE Brazil $^{9}$ & $27-610$ & & $14-28$ & & 0.31 & \\
\hline & & & & & & & 0.33 & \\
\hline Meliaceae & Xylocarpus granatum & E. India ${ }^{15}$ & 0.9 & & 0.47 & & 0.55 & \\
\hline \multirow[t]{6}{*}{ Myrsinaceae } & Aegiceras cornuculatum & Ting Kok, Hong Kong ${ }^{2}$ & 53 & 33 & 17 & 0.63 & 0.31 & 0.50 \\
\hline & & N. Australia ${ }^{14}$ & 97 & & 30 & & 0.31 & \\
\hline & & Shenzhen, China ${ }^{17}$ & 146 & & 85 & & 0.58 & \\
\hline & & Mai Po, Hong Kong ${ }^{11}$ & 281 & 83 & & 0.29 & & \\
\hline & & Hainan Island, China ${ }^{6}$ & & & 27 & & 0.95 & \\
\hline & & & & & & 0.46 & 0.54 & \\
\hline \multirow[t]{3}{*}{ Rhizophoraceae } & Bruguiera cylindrica & E. India ${ }^{15}$ & 0.9 & & 1.2 & & 1.23 & \\
\hline & Bruguiera gymnorrhiza & Hainan Island, China ${ }^{6}$ & & & 5.7 & & 0.20 & \\
\hline & Bruguiera sexangula & Hainan Island, China ${ }^{6}$ & & & 30 & & 1.10 & \\
\hline
\end{tabular}


Table 1 (continued)

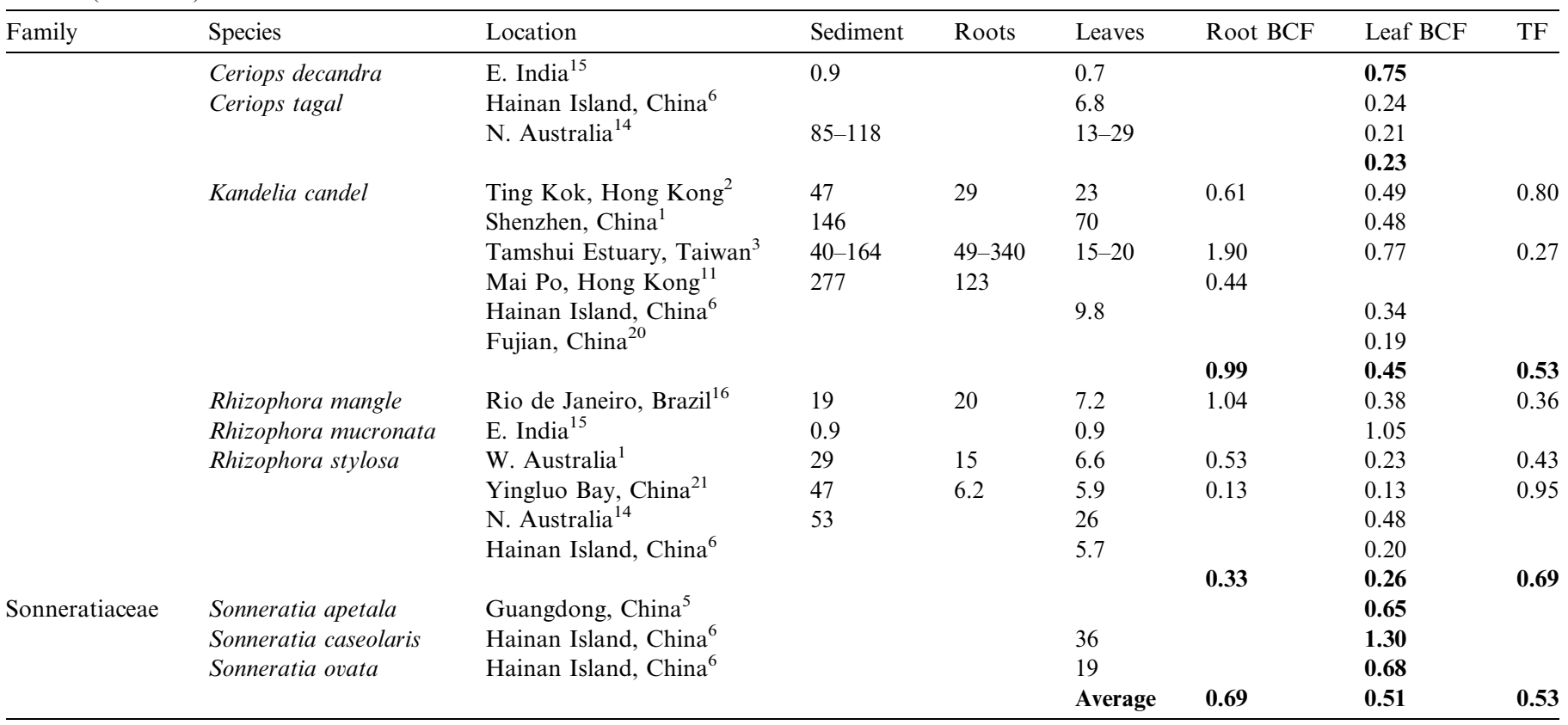

${ }^{1}$ Alongi et al. (2003); ${ }^{2}$ Chen et al. (2003); ${ }^{3}$ Chiu and Chou (1991); ${ }^{4}$ Defew et al. (2005); ${ }^{5}$ Han et al. (2004); ${ }^{6}$ Lian et al. (1999); ${ }^{7}$ MacFarlane (2002); ${ }^{8}$ MacFarlane et al. (2003); ${ }^{9}$ Machado et al. (2002); ${ }^{10}$ Miao and Chen (1998); ${ }^{11}$ Ong Che (1999); ${ }^{12}$ Peng et al. (1997); ${ }^{13}$ Sadiq and Zaidi (1994); ${ }^{14}$ Saenger et al. (1990); ${ }^{15}$ Sarangi et al. (2002); ${ }^{16}$ Silva et al. (1990); ${ }^{17}$ Tam et al. (1995); ${ }^{18}$ Thomas and Fernandez (1997); ${ }^{19}$ Zahir et al. (2004); ${ }^{20}$ Zheng and Lin (1996); ${ }^{21}$ Zheng et al. (1997).

Values in bold represent averages for each species.

With these limitations in mind, and on the basis of the aforementioned criteria, a final dataset of 19 species from seven families across a range of geographical locations and heavy metal contaminant profiles were examined (Table 1a-c).

\subsection{Statistical analyses}

\subsubsection{Species level analyses}

Relationships between sediment metal loadings and BCFs across species were assessed via the Spearman's correlation coefficient. Species were grouped in terms of their dominant adaptation for dealing with $\mathrm{Na}^{+}$and other ions in order to maintain osmotic balance within saline environments. Representatives from the families Acanthaceae, Avicenniaceae and Myrsinaceae were grouped as salt secretors (presence of salt glands), while families without salt glands were grouped as non-secretors (absence of salt glands in leaves is often associated with exclusion, i.e. barriers to salt accumulation at the root level) (Tomlinson, 1986). Differences between secretors and non-secretors in terms of root BCFs, leaf BCFs and TFs for each metal separately were assessed with the two sample unbalanced $t$-test (Zar, 1999).

Where sufficient data were available (i.e. for leaf BCFs) differences for each metal were compared among family and genera employing a one way unbalanced ANOVA (Zar, 1999). These analyses were performed in Statistica for Windows (StatSoft, 1995). Data for all species were compared among the three metals for root $\mathrm{BCFs}$, leaf BCFs and TFs to assess if patterns varied among metals employing mixed model ANOVAs with metal as a fixed effect and species as a random effect (Pinheiro and Bates, 2000). In this context, a mixed model ANOVA is conceptually similar to a paired $t$-test, except that there are three groups (metals), instead of the two in a paired $t$-test. Comparisons among metal BCFs and TFs were made within species, thus making corrections for phylogenetic effects unnecessary. Mixed models were fitted using the nlme package for R (Pinheiro et al., 2006).

\subsubsection{Analyses within a phylogenetic context}

Usual statistical methods assume that each data point is an independent sample. However, closely related species may not be statistically independent as they share a common evolutionary history thus biasing any cross-species analysis of broad scale patterns (Harvey and Pagel, 1991). Recent studies suggest that this lack of independence is an important property of virtually all cross-species datasets and their analysis (Freckleton et al., 2002; Blomberg et al., 2003). Despite this, analyses of species responses to contaminants in ecotoxicology have rarely, if ever, considered this problem. To our knowledge, this is the first instance of species accumulation patterns being analysed quantitatively within a phylogenetic framework. Approaches to the analysis of cross-species datasets have mainly employed phylogenetically independent contrasts (Felsenstein, 1985) or equivalently, generalised least squares (GLS) linear modelling 
methods (Martins and Hansen, 1997; Garland and Ives, 2000; Rohlf, 2001). Where sufficient data were available to allow analysis within a phylogenetic context, we employed phylogenetic GLS methods to examine differences between secretors and non-secretors in terms of leaf BCFs for each metal separately.

A matrix of fixed correlations specifying dependence among species observations was derived from shared branch lengths (fixed branch lengths $=1$ ) based on the phylogenetic topology of Parani et al. (2002) above the family level. Relationships among genera and among species within genera were based on Parani et al. (2002) where possible, supplemented with a composite of several phylogenies (i.e. Rhizophoraceae (Lakshmi et al., 2002; Shi et al., 2002), Rhizophora spp. (Duke, 2002; Duke et al., 2002) and Sonneratia spp. (Shi et al., 2000)). Significant differences among parameter estimates for each category of secreting or non-secreting species were assessed via the $t$ statistic. Analyses were performed using R 2.3.1 (R Development Core Team, 2006) with the Analyses of Phylogenetics and Evolution package (ape 1.8-4 (Paradis et al., 2004)) and the nlme package (nlme 3.1-75 (Pinheiro et al., 2006)).

Assigning branch lengths equal to 1 assumes that all speciation events are present in the phylogeny, and that traits change only at speciation events. In order to explore the effect of different branch length assumptions on our analysis, we reanalysed our data using Grafen's branch lengths $(\rho=1)$ (Grafen, 1989), which sets the node height proportional to the number of taxa above it in the phylogenetic tree. There was a high concordance in the results obtained between the two techniques. We thus chose to report the results for unit branch lengths, as the differences between the two approaches did not alter the interpretation of results.

\section{Results}

Copper was accumulated in root tissue to levels similar to environmental concentrations, with an average root $\mathrm{BCF}$ of $1.1 \pm 0.2$ (SE). Translocation of $\mathrm{Cu}$ was limited, with concentrations of accumulated $\mathrm{Cu} \mathrm{50 \%} \mathrm{lower} \mathrm{in} \mathrm{leaves}$ than roots. Species exhibited an average $\mathrm{Cu}$ leaf BCF of $0.47 \pm 0.07$, and translocation factor of $0.52 \pm 0.09$ (Table 1a). Copper root BCFs remained constant across sediment loadings (sediment vs. root BCF, Spearman $r=-0.33$, ns., $p>0.05$ ); leaf BCFs and TFs tended be to lower at higher sediment $\mathrm{Cu}$ concentrations suggesting regulation of translocation (sediment vs. leaf BCF, $r=-0.54, p<0.05$ ). No significant differences were observed between salt secreting and non-secreting species in terms of $\mathrm{Cu}$ root $\mathrm{BCF}$ $\left(t_{12}=-0.32, p>0.05\right)$, leaf $\mathrm{BCF}\left(t_{38}=0.73, p>0.05\right)$ or $\mathrm{TF}\left(t_{9}=0.58, p>0.05\right)$. Copper leaf BCFs were similar among families and genera (leaf BCF, 0.34-0.58; family $F_{5,33}=1.12, \quad p>0.05 ; \quad$ genera $\left.F_{8,30}=0.89, \quad p>0.05\right)$ (Table 1a).
Lead was accumulated in root tissue to levels similar to environmental concentrations with an average root BCF of $0.84 \pm 0.21$. Translocation of non-essential $\mathrm{Pb}$ was minimal and the lowest of all metals with concentrations of accumulated $\mathrm{Pb}$ reaching leaf tissue only $30 \%$ that of roots. Species exhibited an average $\mathrm{Pb}$ leaf $\mathrm{BCF}$ of $0.11 \pm 0.02$, and an average TF of $0.31 \pm 0.07$ (Table 1b). Root BCFs were similar across sediment loadings (sediment vs. root BCF, $r=0.09$, n.s., $p>0.05$ ). Lead leaf BCFs and TFs were consistently low, suggesting exclusion of $\mathrm{Pb}$ from acropetal transport (sediment vs. leaf BCF, $r=-0.11$, n.s., $p>0.05$ ). No significant differences were observed between salt secreting and non-secreting species for $\mathrm{Pb}$ root $\mathrm{BCF}\left(t_{12}=-1.21, p>0.05\right)$, leaf $\mathrm{BCF}\left(t_{30}=1.34, p>0.05\right)$ or TF $\left(t_{9}=0.92, p>0.05\right)$. Lead leaf BCFs were similar among families and genera (leaf BCF, family $F_{5,26}=0.80$, $p>0.05$; genera $F_{8,23}=0.76, p>0.05$ ) (Table $1 b$ ).

Zinc was accumulated in root tissue of mangroves to concentrations around $70 \%$ of environmental concentrations with an average root BCF of $0.69 \pm 0.1$. Translocation of $\mathrm{Zn}$ was similar to the essential metal $\mathrm{Cu}$ with concentrations of accumulated $\mathrm{Zn}$ in leaf tissue $50 \%$ that of roots. Species exhibited leaf $\mathrm{Zn}$ BCFs of $0.51 \pm 0.05$, and $\mathrm{Zn}$ TFs of $0.53 \pm 0.07$ (Table 1c). Root BCFs were similar across sediment loadings (sediment vs. root $\mathrm{BCF}$ $r=0.05$, n.s., $p>0.05$ ). Zn leaf BCFs were lower at higher $\mathrm{Zn}$ sediment/root concentrations, indicative of regulation to acropetal $\mathrm{Zn}$ transport (sediment vs. leaf $\mathrm{BCF}$ $r=-0.63, p<0.05$ ). No significant differences in $\mathrm{Zn}$ leaf BCFs were observed among family or genera (leaf BCF, $0.34-0.58$, family $F_{5,33}=0.89, p>0.05$; genera $F_{8,30}=$ $0.94, p<0.05)$. Similarly, no significant differences were observed between salt secreting and non-secreting species for $\mathrm{Zn}$ root $\mathrm{BCF}\left(t_{12}=-0.42, p>0.05\right)$, leaf $\mathrm{BCF}$ $\left(t_{37}=-0.50, \quad p>0.05\right) \quad$ or $\mathrm{TF} \quad\left(t_{9}=-0.34, \quad p>0.05\right)$ (Table 1c).

When the raw (species level) data were corrected for phylogenetic relatedness, similar results were observed suggesting patterns in data were not an artefact of correlated data due to the close relationships of some species. Leaf $\mathrm{BCF}$ s for $\mathrm{Cu}, \mathrm{Pb}$ and $\mathrm{Zn}$ were similar regardless of whether species were classified as salt secreting or non-secreting species $\left(\mathrm{Cu}, t_{16}=-0.99, p>0.05 ; \mathrm{Pb}, t_{12}=-0.67, p>0.05\right.$; $\left.\mathrm{Zn}, t_{16}=-0.85, p>0.05\right)$.

When comparing patterns among metals, significantly lower $\mathrm{Pb}$ was accumulated in roots than $\mathrm{Cu}\left(t_{10}=-2.92\right.$, $\mathrm{df}=10, p<0.05)$. There were no differences between $\mathrm{Zn}$ and $\mathrm{Cu}$ BCFs $\left(t_{10}=-2.04, p>0.05\right)$ nor any difference between $\mathrm{Zn}$ and $\mathrm{Pb}$ BCFs across mangrove species $\left(t_{10}=0.88, p>0.05\right)$. Mangroves accumulated significantly lower levels of $\mathrm{Pb}$ in leaves compared with both $\mathrm{Cu}$ $\left(t_{22}=3.69, p<0.01\right)$ and $\mathrm{Zn}\left(t_{22}=5.39, p<0.01\right)$. There was no significant difference in leaf BCFs between $\mathrm{Cu}$ and $\mathrm{Zn}\left(t_{22}=1.70, p=0.10\right)$. Translocation factors among species were broadly similar for all metals $(\mathrm{Cu}$ vs. $\mathrm{Pb}$, $t_{8}=-1.25, p>0.05 ; \mathrm{Cu}$ vs. $\mathrm{Zn}, t_{8}=-0.06, p>0.05 ; \mathrm{Pb}$ vs. $\mathrm{Zn}, t_{8}=1.19, p>0.05$ ). 


\section{Discussion}

Despite the true mangroves being a taxonomically diverse group, metal accumulation and partitioning patterns for all metals examined were broadly similar across genera and families. Metal accumulation patterns were also similar regardless of whether species were secretors or nonsecretors.

In conventional statistical methods, data are assumed to be sampled randomly and independently. When comparative data such as accumulation factors are sampled across a phylogeny from what is available in the literature, and differences tested among taxa groups, values may not be independent due to closely related species with a common ancestry sharing similar traits (i.e. ability to accumulate a particular metal or salt secretion), thereby biasing analyses and interpretation (Harvey and Pagel, 1991). Similar metal accumulation strategies among secretors or non-secretors were maintained after phylogenetic correction of data, suggesting the lack of differences observed among groups from species level analyses were not unduly influenced by relatedness among species.

Copper, $\mathrm{Pb}$ and $\mathrm{Zn}$ were accumulated in root tissue to concentrations equal to or less than adjacent sediment concentrations (root BCFs 0.69-1.1). Little translocation was observed, with metal concentrations up to an order of magnitude lower in leaf tissue. Essential metals $(\mathrm{Cu}$ and $\mathrm{Zn}$; TFs of 0.52 and 0.53 , and leaf BCFs of 0.47 and 0.51 , respectively) showed greater mobility than non-essential metals $(\mathrm{Pb}$; TF of 0.31 and leaf BCF of 0.11$)$. Levels of $\mathrm{Cu}, \mathrm{Pb}$ and $\mathrm{Zn}$ in tissues largely reflect trace metal concentrations found in most terrestrial plant species $\mathrm{Cu}=$ $10 \mu \mathrm{g} \mathrm{g}^{-1} ; \mathrm{Pb}=1 \mu \mathrm{g} \mathrm{g}^{-1} ; \mathrm{Zn}=50 \mu \mathrm{g} \mathrm{g}^{-1}$ (Markert, 1993). Thus mangroves as a group tend to operate as excluder species for non-essential metals, i.e. $\mathrm{Pb}$, and regulators of essential metals, i.e. $\mathrm{Cu}$ and $\mathrm{Zn}$ (Baker, 1981).

In terms of patterns in metal accumulation with variations in sediment metal loading, relative proportions of metal accumulated from sediment to roots were similar regardless of environmental concentration for all metals examined. Leaf BCFs for the essential metals $\mathrm{Cu}$ and $\mathrm{Zn}$ decreased as environmental concentrations increased. These patterns perhaps suggest that at low metal concentrations plants translocate from root to shoot to meet metabolic requirements, while at higher concentrations metal translocation is restricted to prevent toxicity (Baker, 1981). Non-essential metals such as $\mathrm{Pb}$ are excluded from leaf tissue regardless of environmental concentrations.

A number of possible mechanisms may account for the low observed metal accumulation in mangroves. The initial bioavailability of sediment metals in estuarine situations is often low. Due to sediments generally being anoxic, waterlogged and of low $\mathrm{pH}$, metals are often precipitated as insoluble sulphides (Lacerda, 1997). Metals may be adsorbed on ion exchange sites of fine silts/clays, incorporated into the lattice structure of clay, or adsorbed within iron and manganese colloidal oxide compounds (Harbison,
1986). The high organic content of detritus rich sediments facilitates complexation with refractory organics, and as such is a major contributor to low metal availability (MacFarlane et al., 2003). Additionally, high salinity facilitates the formation of metal-chloride complexes which are less bioavailable for uptake than free metals (Greger, 2004).

Possible physiological mechanisms responsible for variation in uptake and translocation at the root level include processes at the root's rhizosphere. Small-scale variation in uptake among families/genera may be attributed to the adaptation of aerial root structures such as pneumatophores with lenticels for gaseous exchange in some species and the absence of these adaptations in others. An oxidised rhizosphere within the anoxic soil environment may confer a reduction in complexing sulphides, a lowered stability of iron plaques, resulting in higher concentrations in the exchangeable form for some trace metals (Lacerda and Abrao, 1984; Lacerda, 1993). Indeed, trends towards higher root BCFs seem to be characteristic of species with pneumatophores (i.e. Avicennia spp.) and species that inhabit less frequently inundated habitats where sediments are less anoxic (i.e. Kandelia and Aegiceras spp.).

The accumulation of $\mathrm{Cu}, \mathrm{Pb}$ and $\mathrm{Zn}$ by roots (root $\mathrm{BCFs} \sim 1$ ) and restricted translocation of $\mathrm{Cu}, \mathrm{Zn}$ and especially $\mathrm{Pb}$ across species found in the present survey, reflect patterns of accumulation and distribution from laboratory studies with $A$. marina. MacFarlane and Burchett (2000, 2002) found $\mathrm{Cu}, \mathrm{Pb}$ and $\mathrm{Zn}$ in $A$. marina roots at concentrations similar to sediment loadings. Through SEM $\mathrm{X}$-ray microanalysis, it was found that metals were mainly localised in cell walls (i.e. apoplastic transport implicated through cationic exchange with cell wall associated carboxylic groups). The epidermal layers operated as a barrier reducing the transport of $\mathrm{Pb}$ while the endodermis restricted movement of $\mathrm{Cu}, \mathrm{Pb}$ and $\mathrm{Zn}$ into the stele (i.e. Casparian strip mediated delimitation of apoplastic transport).

Non-secreting species (e.g. Sonneratia, Bruguiera and Rhizophora spp.) typically possess low concentrations of salt (i.e. $\mathrm{NaCl}$ ) in the xylem with $\mathrm{Na}^{+}$concentrations around one hundredth that of sea water and uptake being regulated predominantly at the root endodermis (Tomlinson, 1986). Salt secreting species (e.g. Avicennia spp.) exhibit a greater mobility of $\mathrm{Na}^{+}$ions with concentrations approximately one tenth that of seawater in xylem sap with salt glands reducing overall $\mathrm{Na}$ concentrations in leaves (Lawton et al., 1981; Tomlinson, 1986). Despite these physiological differences in $\mathrm{Na}$ uptake among species, patterns of metallic cation $\left(\mathrm{Cu}^{2+}, \mathrm{Pb}^{2+}\right.$ and $\left.\mathrm{Zn}^{2+}\right)$ uptake by roots and translocation to the shoot were broadly similar for both salt secreting and non-secreting species. It is probable that metal influx and regulation of transport in mangroves are likely to be achieved through a variety of pathways in addition to those responsible for sodium influx/transport.

MacFarlane and Burchett $(2000,2002)$ found that $\mathrm{Pb}$ translocation to leaves in A. marina was low. Accumulated $\mathrm{Pb}$ was largely immobile, cell wall bound and/or 
sequestered predominantly in the epidermal layers of the root. Zinc (presumably chelated with organic acids) and $\mathrm{Cu}$ (primarily amino acid associated) were translocated to leaf tissue, though concentrations were an order of magnitude lower than in roots $(\mathrm{TF}<0.1)$. Indeed, these patterns of translocation broadly reflect cross-species trends despite differences in salt regulation strategies. Although mangroves have been shown to excrete metals $(\mathrm{Cu}$ and $\mathrm{Zn}, A$. marina; MacFarlane and Burchett, 2002) from salt glands concomitantly with $\mathrm{Na}$, secretion does not significantly alter overall distribution patterns of metals in leaf tissue among families, or when comparing secretors to nonsecretors.

For phytoremediation initiatives, phytoextraction of contaminants from the sediment requires translocation from root to shoot to enable harvest and removal of contaminants (Kumar et al., 1995). For phytoextraction to be viable, 'hyperaccumulation' of contaminants is required by species tolerant to high concentrations of bioavailable metal, i.e. leaf BCFs and TFs greater than one (Ma et al., 2001b; Baker and Whiting, 2002). When comparing leaf BCFs in the current survey to established hyperaccumulators such as the fern Pteris vittata (Ma et al., 2001a) with As BCFs greater than 100 , the $\mathrm{BCF}$ values in mangroves are relatively low. However, leaf $\mathrm{BCF}$ s for $\mathrm{Zn}$ in other hyperaccumulating terrestrial plant species are lower than for As, i.e. up to 40 in Thlaspi caerulescens (Zhao et al., 2003). Generally, results are presented in absolute values rather than as BCF or TF. Plants with $>500 \mu \mathrm{g} \mathrm{g}^{-1} \mathrm{Cu}$ or $10000 \mu \mathrm{g} \mathrm{g}^{-1} \mathrm{Zn}$ in their tissue have been classified as hyperaccumulators (Brooks, 1998), whereas the $\mathrm{Pb}$ hyperaccumulator, Brassica juncea, has been reported as accumulating $18812 \mu \mathrm{g} \mathrm{g}^{-1} \mathrm{~Pb}$ in shoots (McGrath, 1998). Mangroves exhibit uptake and translocation of metals well below levels found in established hyperaccumulators. Thus mangroves in remediation initiatives are perhaps best employed as phytostabilisers (Salt et al., 1995), functioning as long-term sinks for metallic contaminants. Not only do mangrove sediments reduce many metals in anoxic sediments, thereby limiting bioavailability and mobility, the presence of mangrove trees stabilises sediments physically, thereby reducing sediment (and metal) export to surrounding waters. Furthermore, levels of metals exported from mangroves through leaf litter decomposition are estimated to be very low i.e. $0.01,0.02$ and $0.005 \mathrm{~mol} \mathrm{ha}^{-1}$ year $^{-1}$ for $\mathrm{Cu}, \mathrm{Zn}$ and $\mathrm{Pb}$, respectively, for $R$. mangle (Silva et al., 2006), suggesting much of the metal budget is retained within mangrove systems affording protection for adjacent estuarine/marine systems.

\section{Conclusions}

Mangroves are a phylogenetically heterogeneous group with differing adaptive strategies for dealing with the challenge of highly anoxic and saline environments. Despite these differences, metal accumulation and partitioning for $\mathrm{Cu}, \mathrm{Pb}$ and $\mathrm{Zn}$ were found to be similar across genera and families in the current study. Equally, patterns of metal accumulation were also similar regardless of whether taxa were classified as salt secreting or non-secreting species. Metals tended to be accumulated in roots to concentrations similar to those of adjacent sediments while metal concentrations in leaves were half that of roots or lower. Essential metals were more mobile than non-essential metals suggesting mangroves tend to operate as excluder species for nonessential metals and regulators of essential metals. In a phytoremediative context, mangrove ecosystems are more appropriate candidates for phytostabilisation, retaining metallic inputs and thereby reducing transport to adjacent systems.

\section{Acknowledgement}

Funding support for this project was generously provided by an Australian Research Council Discovery Grant (DP0663454).

\section{References}

Alongi, D.M., Clough, B.F., Dixon, P., Tirendi, F., 2003. Nutrient partitioning and storage in arid-zone forests of the mangroves Rhizophora stylosa and Avicennia marina. Trees 17, 51-60.

Baker, A.J.M., 1981. Accumulators and excluders: strategies in the response of plants to heavy metals. J. Plant Nutr. 3, 643-656.

Baker, A.J.M., Whiting, S.N., 2002. In search of the holy grail - a further step in understanding metal hyperaccumulation? New Phytol. 155, 14.

Blomberg, S.P., Garland, T., Ives, A.R., 2003. Testing for phylogenetic signal in comparative data: behavioral traits are more labile. Evolution 57, 717-745.

Brooks, R.R., 1998. Geobotany and hyperaccumulators. In: Brooks, R.R. (Ed.), Plants that Hyperaccumulate Heavy Metals. University Press, Cambridge, pp. 55-94.

Chen, X.Y., Tsang, E.P.K., Chan, A.L.W., 2003. Heavy metal contents in sediments, mangroves and bivalves from Ting Kok, Hong Kong. China Environ. Sci. 23, 480-484.

Chiu, C.Y., Chou, C.H., 1991. The distribution and influence of heavy metals in mangrove forests of the Tamshui estuary in Taiwan. Soil Sci. Plant Nutr. 37, 659-669.

Chiu, C.Y., Hsiu, F.-S., Chen, S.-S., Chou, C.H., 1995. Reduced toxicity of $\mathrm{Cu}$ and $\mathrm{Zn}$ to mangrove seedlings (Kandelia candel (L.) Druce.) in saline environments. Bot. Bull. Acad. Sinica 36, 19-24.

Defew, L.H., Mair, J.M., Guzman, H.M., 2005. An assessment of metal contamination in mangrove sediments and leaves from Punta Mala Bay, Pacific Panama. Mar. Pollut. Bull. 50, 547-552.

Duke, N.C., 2002. Mangrove phenologies and the factors influencing them in the Australasian region. In: de Lacerda, L.D. (Ed.), Mangrove Ecosystems - Function and Management. Springer, Berlin, pp. 217233.

Duke, N.C., Lo, E.Y.Y., Sun, M., 2002. Global distribution and genetic discontinuities of mangroves - emerging patterns in the evolution of Rhizophora. Trees 16, 65-79.

Eong, O.J., 1995. The ecology of mangrove conservation and management. Hydrobiologia 295, 343-351.

Felsenstein, J., 1985. Phylogenies and the comparative method. Am. Nat. $125,1-15$.

Field, C.D., 1995. Journey amongst Mangroves. International Society for Mangrove Ecosystems, Okinawa, 140pp.

Freckleton, R.P., Harvey, P.H., Pagel, M.D., 2002. Phylogenetic analysis and comparative data: a test and review of evidence. Am. Nat. 160, $712-726$. 
Garland, T.J., Ives, A.R., 2000. Using the past to predict the present: confidence intervals for regression equations in phylogenetic comparative methods. Am. Nat. 155, 346-364.

Grafen, A., 1989. The phylogenetic regression. Philos. T. R. Soc. B 326, $119-157$.

Greger, M., 2004. Metal availability, uptake, transport and accumulation in plants. In: Prasad, M.N.V. (Ed.), Heavy Metal Stress in Plants: From Biomolecules to Ecosystems. Springer, Berlin, pp. 1-27.

Han, W., Zhao, Y., Lu, C., Lin, P., 2004. Biological accumulation and circulation of seven metal elements of Sonneratia apetala plantation in Leizhou, Guangdong. Chin. J. Appl. Environ. Biol. 10, 27-34.

Harbison, P., 1986. Mangrove muds - a sink and a source for trace metals. Mar. Pollut. Bull. 17, 246-250.

Harty, C., 1997. Mangroves in New South Wales and Victoria. Vista Publications, Melbourne, 47pp.

Harvey, P.H., Pagel, M.D., 1991. The Comparative Method in Evolutionary Biology. Oxford University Press, Oxford.

Hutchings, P., Saenger, P., 1987. The Ecology of Mangroves. University of Queensland Press, St Lucia, 388pp.

Irvine, I., Birch, G.F., 1998. Distribution of heavy metals in surficial sediments of Port Jackson, Sydney, New South Wales. Aust. J. Earth Sci. 45, 297-304.

Kramer, D., Preston, J., 1978. A modified method of X-ray microanalysis of bulk-frozen plant tissue and its application to the problem of salt exclusion to mangrove roots. Microsc. Acta 2, 193-200.

Kumar, P.B.A.N., Dushenko, V., Motto, H., Raskin, I., 1995. Phytoextraction: the use of plants to remove heavy metals from soils. Environ. Sci. Technol. 29, 1232-1238.

Lacerda, L.D., 1993. The biogeochemistry and trace metal distribution of mangrove rhizospheres. Biotropica 25, 252.

Lacerda, L.D., 1997. Trace metals in mangrove plants: why such low concentrations? In: Kjerfve, B., Lacerda, L.D., Diop, H.S. (Eds.), Mangrove Ecosystem Studies in Latin America and Africa. UNESCO, Paris, pp. 171-178.

Lacerda, L.D., Abrao, J.J., 1984. Heavy metal accumulation by mangrove and saltmarsh intertidal sediments. Rev. Bras. Biol. 7, 49-52.

Lakshmi, M., Parani, M., Parida, A., 2002. Molecular phylogeny of mangroves. IX Molecular markers assisted intra-specific variation and species relationships in the Indian mangrove tribe Rhizophoreae. Aquat. Bot. 74, 201-217.

Lawton, J.R., Todd, A., Naidoo, D.K., 1981. Preliminary investigations into the structure of the roots of mangroves, Avicennia marina and Bruguiera gymnorrhiza, in relation to ion uptake. New Phytol. 88, 713722.

Lian, Y., Xu, J., Lin, P., Meguro, S., 1999. Five heavy metals in propagules of ten mangrove species of China. J. Wood Sci. 45, 343347.

Ma, L.Q., Komar, K.M., Tu, C., Zhang, W., Cai, Y., Kennelley, E.D., 2001a. A fern that hyperaccumulates arsenic. Nature 409, 579.

Ma, L.Q., Komar, K.M., Tu, C., Zhang, W., Cai, Y., Kennelley, E.D., 2001b. Addendum: a fern that hyperaccumulates arsenic. Nature 411, 438.

MacFarlane, G.R., 2002. Leaf biochemical parameters in Avicennia marina (Forsk.) Vierh as potential biomarkers of heavy metal stress in estuarine ecosystems. Mar. Pollut. Bull. 44, 244-256.

MacFarlane, G.R., Burchett, M.D., 1999. Zinc distribution and excretion in the leaves of the grey mangrove, Avicennia marina (Forsk.) Vierh. Environ. Exp. Bot. 41, 167-175.

MacFarlane, G.R., Burchett, M.D., 2000. Cellular distribution of copper, lead and zinc in the grey mangrove, Avicennia marina (Forsk.) Vierh. Aquat. Bot. 68, 45-59.

MacFarlane, G.R., Burchett, M.D., 2002. Toxicity, growth and accumulation relationships of copper, lead and zinc in the grey mangrove Avicennia marina (Forsk.) Vierh. Mar. Environ. Res. 54, 65-84.

MacFarlane, G.R., Pulkownik, A., Burchett, M.D., 2003. Accumulation and distribution of heavy metals in the grey mangrove, Avicennia marina (Forsk.) Vierh.: biological indication potential. Environ. Pollut. 123, 139-151.
Machado, W., Silva-Filho, E.V., Oliveira, R.R., Lacerda, L.D., 2002. Trace metal retention in mangrove ecosystems in Guanabara Bay, SE Brazil. Mar. Pollut. Bull. 44, 1277-1280.

Marchand, C., Lallier-Verges, E., Baltzer, F., Alberic, P., Cossa, D., Baillif, P., 2006. Heavy metals distribution in mangrove sediments along the mobile coastline of French Guiana. Mar. Chem. 98, 1-17.

Markert, B., 1993. Instrumental analysis of plants. In: Markert, B. (Ed.), Plants as Biomonitors. Indicators of Heavy Metals in the Terrestrial Environment. VCH, Weinheim, pp. 65-103.

Martins, E.P., Hansen, T.F., 1997. Phylogenies and the comparative method: a general approach to incorporating phylogenetic information into the analysis of interspecific data. Am. Nat. 149, 646-667.

McGrath, S.P., 1998. Phytoextraction for soil remediation. In: Brooks, R.R. (Ed.), Plants that Hyperaccumulate Heavy Metals. University Press, Cambridge, pp. 261-287.

Miao, S.Y., Chen, G.Z., 1998. Allocation and migration of lead in simulated wetland system of Kandelia candel. China Environ. Sci. 18, $48-51$.

Mills, W.B., 1995. Water Quality Assessment: A Screening Procedure for Toxic and Conventional Pollutants in Surface and Ground WaterPart 1. US EPA, Georgia.

Neumann, D., Nieden, U.Z., Lichtenberger, O., Leopold, I., 1995. How does Armeria maritima tolerate high metal concentrations? J. Plant Physiol. 146, 704-717.

Ong Che, R.G., 1999. Concentration of 7 heavy metals in sediments and mangrove root samples from Mai Po, Hong Kong. Mar. Pollut. Bull. 39, 269-279.

Paradis, E., Claude, J., Strimmer, K., 2004. APE: analysis of phylogenetics and evolution in R language. Bioinformatics 20, 289-290.

Parani, M., Jithesh, M.N., Lakshmi, M., Parida, A., 2002. Cloning and characterization of a gene encoding ubiquitin conjugating enzyme from the mangrove species Avicennia marina (Forsk.) Vierh. Indian J. Biotechn. 1, 164-169.

Peng, L., Zheng, W., Li, Z., 1997. Distribution and accumulation of heavy metals in Avicennia marina community in Shenzhen, China. J. Environ. Sci. (China) 9, 427-429.

Peters, E.C., Gassman, N.J., Firman, J.C., Richmond, R.H., Power, E.A., 1997. Ecotoxicology of tropical marine ecosystems. Environ. Toxicol. Chem. 16, 12-40.

Pinheiro, J.C., Bates, D.M., 2000. Mixed-effects Models in S and S-PLUS. Springer, New York, 528pp.

Pinheiro, J., Bates, D., Sarkar, D., 2006. nlme: linear and non-linear mixed effects models, pp. R package version 3.1-75.

R Development Core Team, 2006. R: A Language and Environment for Statistical Computing. R Foundation for Statistical Computing, Vienna.

Rohlf, F.J., 2001. Comparative methods for the analysis of continuous variables: geometric interpretations. Evolution 55, 2143-2160.

Sadiq, M., Zaidi, T.H., 1994. Sediment composition and metal concentrations in mangrove leaves from the Saudi coast of the Arabian Gulf. Sci. Total Environ. 155, 1-8.

Saenger, P., McConchie, D., Clark, M.W., 1990. Mangrove forests as a buffer zone between anthropologically polluted areas and the sea. In: Saenger, P. (Ed.), Proceedings of the 1990 CZM Workshop, Yeppoon, Qld, pp. 280-297.

Salt, D.E., Blaylock, M., Kumar, P.B.A.N., Dushenko, V., Ensley, B.D., Chet, I., Raskin, I., 1995. Phytoremediation: a novel strategy for the removal of toxic metals from the environment using plants. Bio Technol. 13, 468-474.

Sarangi, R.K., Kathiresan, K., Subramanian, A.N., 2002. Metal concentrations in five mangrove species of the Bhitarkanika, Orissa, east coast of India. Indian J. Mar. Sci. 31, 251-253.

Shi, S.H., Huang, Y.L., Tan, F.-X., He, X., Boufford, D.E., 2000. Phylogenetic analysis of the Sonneratiaceae and its relationship to Lythraceae based on ITS sequences of nrDNA. J. Plant Res. 113, 253 258 .

Shi, S.H., Zhong, Y., Huang, Y.L., Du, Y., Qiu, X., Chang, H., 2002. Phylogenetic relationships of the Rhizophoraceae in China based on 
sequences of the chloroplast gene $m a t K$ and the internal transcribed spacer regions of nuclear ribosomal DNA and combined data set. Biochem. Syst. Ecol. 30, 309-319.

Silva, C.A.R., Lacerda, L.D., Rezende, C.E., 1990. Metal reservoir in a red mangrove forest. Biotropica 22, 339-345.

Silva, C.A.R., da Silva, A.P., de Oliveira, S.R., 2006. Concentration, stock and transport rate of heavy metals in a tropical red mangrove, Natal, Brazil. Mar. Chem. 99, 2-11.

StatSoft, I., 1995. STATISTICA for Windows. StatSoft, Inc., Tulsa, OK.

Tam, N.F.Y., Yao, M.W.Y., 1999. Three digestion methods to determine concentrations of $\mathrm{Cu}, \mathrm{Zn}, \mathrm{Cd}, \mathrm{Ni}, \mathrm{Pb}, \mathrm{Cr}, \mathrm{Mn}$, and $\mathrm{Fe}$ in mangrove sediments from Sai Keng, Chek Keng, and Sha Tau Kok, Hong Kong. Bull. Environ. Contam. Toxicol 62, 708-716.

Tam, N.F.Y., Li, S.H., Lan, C.Y., Chen, G.Z., Li, M.S., Wong, Y.S., 1995. Nutrients and heavy metal contamination of plants and sediments in Futian mangrove forest. Hydrobiologia 295, 149-158.

Thomas, C., Eong, O.J., 1984. Effect of heavy metals zinc and lead on Rhizophora mucronata LAM. and Avicennia alba Bl. seedlings. In: Soepadmo, E., Rao, A.N., MacIntosh, D.J. (Eds.), Proceedings of the Asian Symposium on Mangrove Environment, Research and Management, 25-29 August 1980. University of Malaya Press, Kuala Lumpur, pp. 568-574.
Thomas, G., Fernandez, T.V., 1997. Incidence of heavy metals in the mangrove flora and sediments in Kerala, India. Hydrobiologia 352, $77-87$.

Tomlinson, P.B., 1986. The Botany of Mangroves. Cambridge University Press, Cambridge, 413pp.

West, R.J., Thorogood, C.A., Williams, R.J., 1983. Environmental stress causing mangrove 'dieback' in NSW. Aust. Fisheries, 16-20.

Zahir, E., Naqvi, I.I., Zehra, I., 2004. Spatial and temporal variation of heavy metals in mangrove and sediment along Karachi coastal areas, Pakistan. J. Saudi Chem. Soc. 8, 197-202.

Zar, J.H., 1999. Biostatistical Analysis. Prentice Hall, New Jersey, 663pp. Zhao, F.J., Lombi, E., McGrath, S.P., 2003. Assessing the potential for zinc and cadmium phytoremediation with the hyperaccumulator Thlaspi caerulescens. Plant Soil 249, 37-43.

Zheng, W., Lin, P., 1996. Accumulation and distribution of $\mathrm{Cu}, \mathrm{Pb}, \mathrm{Zn}$ and $\mathrm{Cd}$ in Avicennia marina mangrove community of Futian in Shenzhen. Oceanol. Limnol. Sinica, 77.

Zheng, W.J., Chen, X.Y., Lin, P., 1997. Accumulation and biological cycling of heavy metal elements in Rhizophora stylosa mangroves in Yingluo Bay, China. Mar. Ecol. - Prog. Ser. 159, 293-301. 